\title{
Biomechanické faktory rotačního pohybu při přeskocích ve sportovní gymnastice (přehledová studie)
}

\section{Biomechanical factors of rotation movement of vaulting in gymnastics: A review}

\author{
Roman Farana, František Vaverka
}

\author{
Pedagogická fakulta Ostravské univerzity, Ostrava
}

\begin{abstract}
Abstrakt
Příspěvek vychází z literární rešerše vědeckých studii v oblasti biomechanické analýzy rotačního pohybu ve sportovni gymnastice. V práci vymezujeme kličové biomechanické veličiny rotačního pohybu a uvádíme hlavní závěry výzkumných studií z oblasti biomechanické analýzy vzniku a kontroly rotačního pohybu ve sportovní gymnastice se zaměřnim na disciplínu přeskok. Cílem příspěvku je předložit přehled vědeckých prací a studií, zabývajících se biomechanickým výzkumem ve sportovní gymnastice, zaměřeným na rotační pohyb v průběhu pohybového děje $v$ preskoku.
\end{abstract}

\begin{abstract}
This paper is based on a literature review of scientific studies in the field of biomechanical analysis of rotational movement in gymnastics. The paper identifies the key biomechanical variables of rotational movement and the main conclusions are given to research studies in the field of biomechanical analysis and control of rotation movement in gymnastics with a focus on discipline vault. The aim of this paper is to present an overview of scientific papers and studies dealing with biomechanical research in artistic gymnastics, focusing on the rotation movement during vault.
\end{abstract}

Klíčová slova: $\quad$ biomechanika, sportovní gymnastika, rotační pohyb, preskok, přehledová studie Keywords: $\quad$ biomechanics, gymnastics, rotation/angular movement, vault, review

Studie vznikla za podpory SGS grantu Ostravské univerzity v Ostravě č. 6117/2011.

\section{ÚVOD}

Ve sportovní gymnastice jsou saltové prvky s obraty považovány za stěžejní cvičební tvary (Yeadon, 1993a). Klíčovou roli v současném provedení přeskoku hraje rotační pohyb kolem horizontální a vertikální osy otáčení. Cviky rotačního charakteru, které jsou ve sportovní gymnastice dominantní, se realizují na základě zisku točivosti vůči horizontální, vertikální či sagitální ose těla, nebo vůči všem uvedeným hlavním osám současně (Krištofič, 1996). S rozvojem gymnastického nářadí (přeskokový stůl, odrazové můstky, doskokové žíněnky) a změnou pravidel sportovní gymnastiky jsou gymnasté a gymnastky nuceni př̌edvádět neustále složitější skoky, což klade nároky na kondiční, technickou i psychickou př́pravu sportovců. Zavedení nového přeskokového nářadí (přeskokový stůl) po $\mathrm{OH}$ v roce 2000 představuje největší změnu ve vývoji gymnastického nářadí za poslední desítky let. Přeskokový stůl byl světovou gymnastickou federací (FIG) představen s hlavním cílem zvýšit bezpečnosti sportovců (Irwin a Kerwin, 2009). Rand (2003) uvádí, že změny v přeskokovém nářadí zkracují dobu učení se dovednostem a umožňují složitější a progresivnější skoky. Větší plocha opory a nový tvar přeskokového stolu má za následek změny v obtížnosti předváděných skoků (Sands, Caine a Borms, 2003). Sportovní gymnasté a gymnastky provádějí ve druhé letové fázi saltové prvky s vícenásobnými rotacemi kolem horizontální i vertikální osy. S rostoucím počtem salt a obratů pak vzrůstá i obtížnost skoku, což vede spolu se správným technickým provedením k vyššímu bodovému hodnocení. Výhodou nového přeskokového nářadí je jeho větší oporná plocha, která umožňuje gymnastům získat více momentu hybnosti, který je považován za kličovou veličinu rotačního pohybu (Prassas, 
2002). Tento fakt ovšem může být nebezpečný pro méně kondičně, technicky i psychicky připravené gymnasty, kterým dává přeskokový stůl pocit většího sebevědomí na úkor bezpečného provedení skoku (Čuk a Ferkolj, 2008).

Ve sportovní gymnastice existuje několik způsobů vzniku a kontroly rotačního pohybu (Gluck, 1982; Yeadon, 1993a; Yeadon, 1993b; Yeadon, 1993c; Yeadon a Kerwin, 1999; Prassas, Kwon a Sands, 2006). Domníváme se, že pochopením biomechanických souvislostí, vedoucích k zisku a kontrole rotačního pohybu, lze přispět ke splnění základních cílů sportovní biomechaniky, ke zlepšení tréninku, zlepšení techniky provedení a prevenci zranění gymnastů (McGinnis, 2005).

\section{CÍLE PRÁCE}

Studie vychází z rozsáhlé literární rešerše vědeckých prací v dané tematické oblasti s cíli:

1. Vymezit klíčové biomechanické znaky rotačního pohybu ve sportovní gymnastice.

2. Předložit přehled vědeckých studií $z$ oblasti biomechanické analýzy vzniku a kontroly rotačního pohybu ve sportovní gymnastice se zaměřením na disciplínu přeskok.

\section{ROTAČNÍ POHYB VE SPORTOVNÍ GYMNASTICE}

Hay (1993) uvádí, že rotační pohyb nastává při pohybu těla po kruhové dráze, okolo osy otáčení tak, že všechny části těla opisují stejný úhel ve stejném čase. Rotační pohyb je možné zaznamenat kolem osy procházející tělem nebo kolem osy, která tělem neprochází (Jandačka a Uhlář, 2011). Prassas et al. (2006) vymezují jako jeden $\mathrm{z}$ klíčových faktorů sportovněgymnastického výkonu rotační schopnost ${ }^{1}$. Většina gymnastických dovedností je tvořena rotačním pohybem kolem horizontální osy otáčení (saltové cvičební tvary, přemet vpřed na přeskoku), kolem vertikální osy otáčení (skoky s obratem), kolem sagitální osy otáčení (přemet stranou, salto stranou) nebo kombinací rotačního pohybu kolem všech uvedených os otáčení (saltové cvičební tvary s obraty). Prassas (1999) vymezuje jako hlavní biomechanické veličiny pro vznik a kontrolu rotačních pohybů ve sportovní gymnastice: moment hybnosti, moment setrvačnosti, moment síly a kinetickou energii rotačního pohybu.

Moment hybnosti (angular momentum) vyjadřuje rovnice:

$$
L=J \omega
$$

kde $\boldsymbol{L}$ je celkový moment hybnosti těla; $\boldsymbol{J}$ je moment setrvačnosti těla vzhledem k ose otáčení; $\boldsymbol{\omega}$ je úhlová rychlost těla kolem osy otáčení. Jednotkou momentu hybnosti je kg. $\mathrm{m}^{2} . \mathrm{s}^{-1}$.

Podle Prassase (1999) popisuje moment hybnosti množství (kvantitu) rotačního pohybu, který gymnasta vyprodukuje na opoře. Je složen ze součtu momentů hybnosti všech tělesných segmentů. Velikost momentu hybnosti je ovlivněna rychlostí otáčení (úhlovou rychlostí), místem, kolem kterého gymnasta rotuje (osa otáčení), a uspořádáním tělesných segmentů vůči sobě navzájem a k ose otáčení (momentem setrvačnosti). V první letové fázi při přeskoku je celkový moment hybnosti klíčovým faktorem určujícím úspěšné provedení skoku a je závislý na velikosti a směru reakčních sil ve fázi odrazu z můstku (Sano et al., 2007). Jandačka a Uhlář (2011) uvádějí, že pokud gymnasta při odrazu energicky vzpaží, získá více momentu hybnosti, který mu pomůže v rotaci. Během letu, např́iklad ve druhé letové fázi v přeskoku, je moment hybnosti konstantní. $\mathrm{V}$ důsledku toho, jak se mění uspořádání tělesných segmentů vůči sobě navzájem, mění se i rychlost otáčení. Například přitažením horních končetin k tělu při obratech kolem vertikální osy gymnasta zrychlí rotaci těla snížením momentu setrvačnosti a zvýšením úhlové rychlosti při zachování stejného momentu hybnosti. Nebo naopak před doskokem upaží, čímž zpomalí rotaci těla zvýšením momentu setrvačnosti a snížením úhlové rychlosti při zachování stejného momentu hybnosti.

$1 \mathrm{~V}$ angličtině používaný pojem ability to rotate. 
Moment setrvačnosti (moment of inertia) vyjadřuje rovnice:

$$
J=m r^{2}
$$

kde $\boldsymbol{J}$ je moment setrvačnosti těla vzhledem k ose otáčení; $\boldsymbol{m}$ je hmotnost těla a $\boldsymbol{r}$ je vzdálenost hmotného bodu od osy otáčení. Jednotkou momentu setrvačnosti je kg.m².

Podle Prassase (1999) vyjadřuje moment setrvačnosti úroveň setrvačnosti těla gymnasty v průběhu rotačního pohybu. Závisí na hmotnosti gymnasty a je charakterizován rozložením hmoty těla gymnasty vzhledem k ose otáčení. Moment setrvačnosti vzrůstá, když gymnasta před doskokem otevře polohu těla (rozbalí se). Naopak pro zrychlení rotace saltového prvku gymnasta sníží moment setrvačnosti tím, že vzhledem k horizontální ose otáčení zaujme těsnější polohu skrčmo.

Moment síly (torque) jen dán vztahem:

$$
M=F r
$$

kde $\boldsymbol{M}$ je moment síly; $\boldsymbol{F}$ je působící síla a $\boldsymbol{r}$ je rameno síly. Jednotkou momentu síly je N.m.

Vyjadřuje rotační účinek síly. Ten závisí na velikosti působící síly a kolmé vzdálenosti od osy otáčení (Prassas, 1999). Podmínkou vzniku otáčivého pohybu je existence ramena síly. Působí li síla mimo okamžitou osu otáčení, vzniká rotační pohyb. Takovou sílu nazýváme excentrická síla. Tento vznik primární rotace je typický spíše pro salta prováděné z místa. Při odrazu z přeskokového můstku při přeskoku není vznik ramene síly nutnou podmínkou, nebot se zde uplatňuje princip setrvačnosti. Naopak u vícenásobných rotací kolem vertikální osy v druhé letové fázi dochází $\mathrm{k}$ vzniku ramene síly ukloněním těla od původní saltové roviny, čímž je posílena rychlost druhotné rotace.

Kinetická energie rotačního pohybu (kinetic energy of rotation) je dána vztahem:

$$
E k=1 / 2 J \omega^{2}
$$

kde $\boldsymbol{J}$ je moment setrvačnosti těla vzhledem k ose otáčení; $\boldsymbol{\omega}$ je úhlová rychlost těla kolem osy otáčení. Jednotkou kinetické energie rotačního pohybu je Joule (J).

Jak uvádí Prassas (1999), popisuje kinetická energie rotačního pohybu množství energie, kterou gymnasta má v důsledku rotačního pohybu. Čím rychleji se pohybuje, tím více má energie.

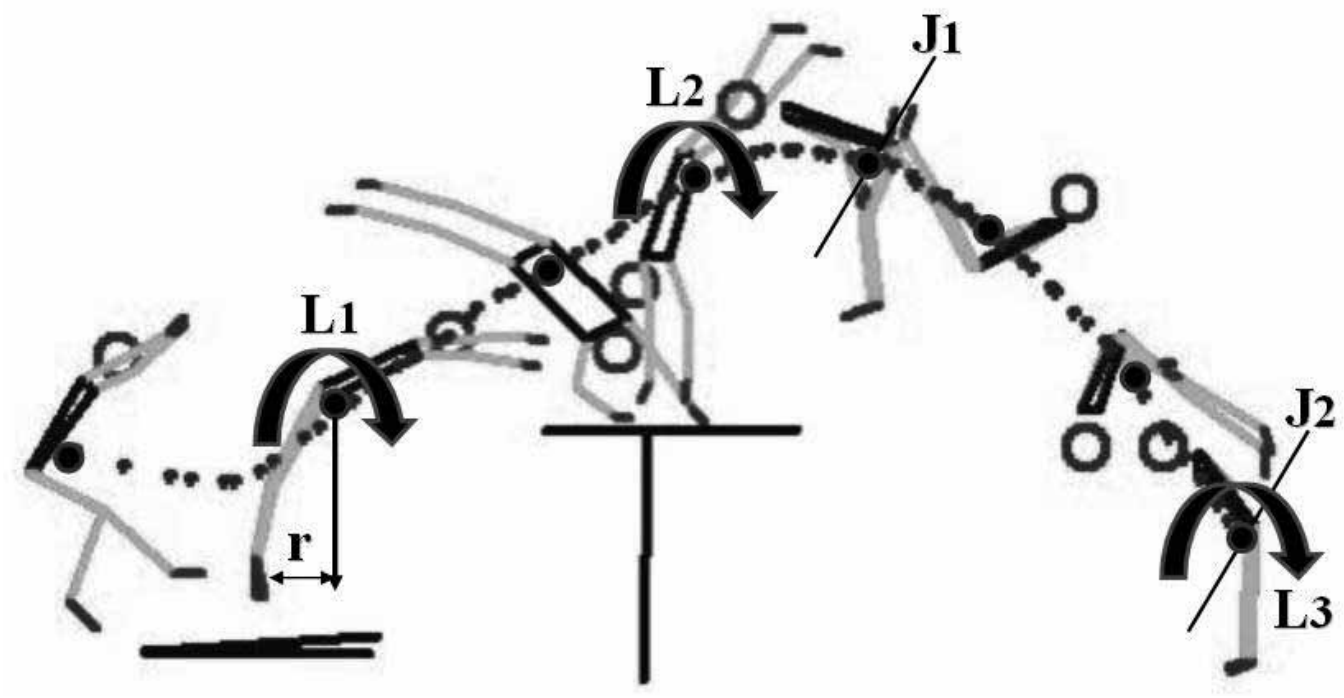


Obrázek 1. Hlavní biomechanické veličiny rotačního pohybu v jednotlivých fázích skoku „Cukahara“ schylmo, kde L1 je celkový moment hybnosti získaný při odrazu z můstku, $\mathbf{r}$ je rameno síly, L2 celkový moment hybnosti získaný při odrazu z přeskokového stolu, J1 moment setrvačnosti kolem horizontální osy otáčení v nejvyšším bodě druhé letové fáze, J2 moment setrvačnosti při doskoku a L3 celkový moment hybnosti při doskoku.

\section{Způsoby vzniku rotačního pohybu ve sportovní gymnastice}

Jako prvotní rotaci označujeme otáčivý pohyb těla kolem horizontální (pravolevé, transverzální) osy otáčení - saltové prvky². Jako druhotná rotace je označován otáčivý pohyb kolem vertikální (výškové, longitudinální) osy otáčení - obraty³. Technika rotačních pohybů rovněž souvisí se somatotypem a tělesnými rozměry gymnastů a gymnastek. Zajímavý názor přinášejí Čuk a Karácsony (2004), kteří tvrdí, že gymnasté, kteří mají širší ramena a boky mají lepší dispozice pro provedení přeskoků s vícenásobnými rotacemi kolem horizontální osy (saltovými prvky), jako jsou „Roche“, „Dragulescu“ nebo „Blanik“. Naproti tomu vyšší gymnasté s užšími rameny a boky mají lepší dispozice pro přeskoky s vícenásobnými rotacemi kolem vertikální osy otáčení (obraty).

\section{Způsoby vzniku prvotní rotace}

Prassas et al. (2006) uvádějí dva základní způsoby vzniku primární rotace. Nejjednodušší a pravděpodobně nejobvyklejší způsob vzniku rotačního pohybu ve sportovní gymnastice je prostřednictvím excentrického odrazu dolních končetin nebo paží z podložky (odrazový můstek, přeskokové nářadí). Excentrický znamená, že směr síly neprochází těžištěm těla gymnasty, ale mimo něj. Tím vzniká moment síly, který uvede tělo do otáčivého pohybu kolem těžiště těla gymnasty. U tohoto způsobu je nutnou podmínkou vznik ramene síly (Hay, 1993). Druhý způsob zisku primární rotace popsal Gluck (1982) a je označován jako „trip effect“. Při tomto způsobu se uplatňuje princip setrvačnosti těla. Pokud gymnasta/gymnastka po rozběhu na přeskoku naskakuje na můstek a chodidla opře proti podložce dostatečně rychle a energicky, začnou se ostatní segmenty těla setrvačně otáčet kolem momentální osy otáčení, která prochází místem kontaktu s podložkou. Pokud provede gymnasta v krátkém časovém intervalu kontaktu s podložkou dynamický odraz, získá potřebnou výšku a dostatek času pro dokončení rotace. Odraz je dokončen a tělo začíná rotovat ve chvíli, kdy je tělo gymnastky překloněno přibližně o $20^{\circ}$ od původní vertikální osy, která je kolmá na horizontální osu tvořenou podložkou (Čuk a Karácsony, 2004). Jednoduchou cestou, jak zvýšit rychlost rotace při této technice, je zvýšení rozběhem získané horizontální rychlosti (Prassas et al., 2006).

\section{Způsoby vzniku druhotné rotace}

Za zásadní studie, zabývající se způsoby vzniku druhotné rotace považujeme práce Yeadona (1993a, 1993b, 1993c, 1994d). Čtyřdílná studie shrnuje závěry teoretických výzkumů vzniku a kontroly druhotné rotace kolem vertikální osy otáčení. Pro analýzu rotačního pohybu je v prvních třech částech studie použit 11segmentový počítačový model lidského těla (Yeadon, Atha a Hales, 1990).

V první části (Yeadon, 1993a) autor používá počítačový model lidského těla k popisu hlavních rotačních pohybů těla za volného letu a vymezuje vztah mezi rotacemi kolem vertikální osy otáčení (obraty), rotacemi kolem horizontální osy otáčení (salty) a úhlem náklonu těla ${ }^{4}$ od vertikální osy otáčení (původní saltové roviny). Při saltech s obraty pracujeme se základními pojmy původní saltová rovina, úhel náklonu těla od této roviny a úhel a směr obratů (Obrázek 2). Yeadon (2000) definuje náklon těla jako úhel mezi vertikální osou otáčení a původní (vertikální) saltovou rovinou. Podle výsledků studie existují dva hlavní typy pohybů, které může rotující lidské tělo za volného letu provést. První způsob je označován

$2 \mathrm{~V}$ angličtině používaný pojem somersaulting nebo somersaulting technique.

$3 \mathrm{~V}$ angličtině používaný pojem twisting nebo twisting technique.

$4 \mathrm{~V}$ angličtině používaný pojem body tilt. 


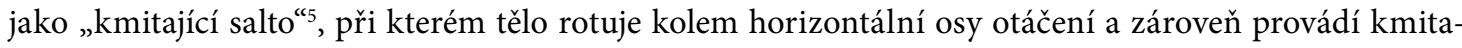
vý pohyb do stran. $V$ průběhu pohybu se tělo naklání stř́ídavě na jednu a na druhou stranu od původní saltové roviny v rozsahu menším než $1 / 4$ obratu $\left(90^{\circ}\right)$. Druhý způsob pohybu je salto, př̀i kterém je obrat kolem vertikální osy prováděn stále ve stejném směru otáčení. $V$ průběhu pohybu je tělo vždy nakloněno ve stejném směru od původní saltové roviny. Při tomto způsobu se úhel otočení s rostoucím počtem obratů zvyšuje.

Závěry studie naznačují, že je možné měnit oba způsoby pohybů prostřednictvím změn v uspořádání tělesných segmentů během letové fáze. Tyto změny mohou působit na velikost momentu setrvačnosti těla nebo na úhel náklonu těla od původní saltové roviny. Změny v uspořádání tělesných segmentů za volného letu mají význam pro zahájení a ukončení obratů. Úhel náklonu dosahuje nejvyšší hodnoty v 1/1/4 průběhu obratu. Proto se ukazuje jako výhodné počkat na dosažení 1/4 obratu a poté zrychlit rotaci snížením momentu setrvačnosti, např. dynamickým přitažením segmentu horních končetin k segmentu trupu.

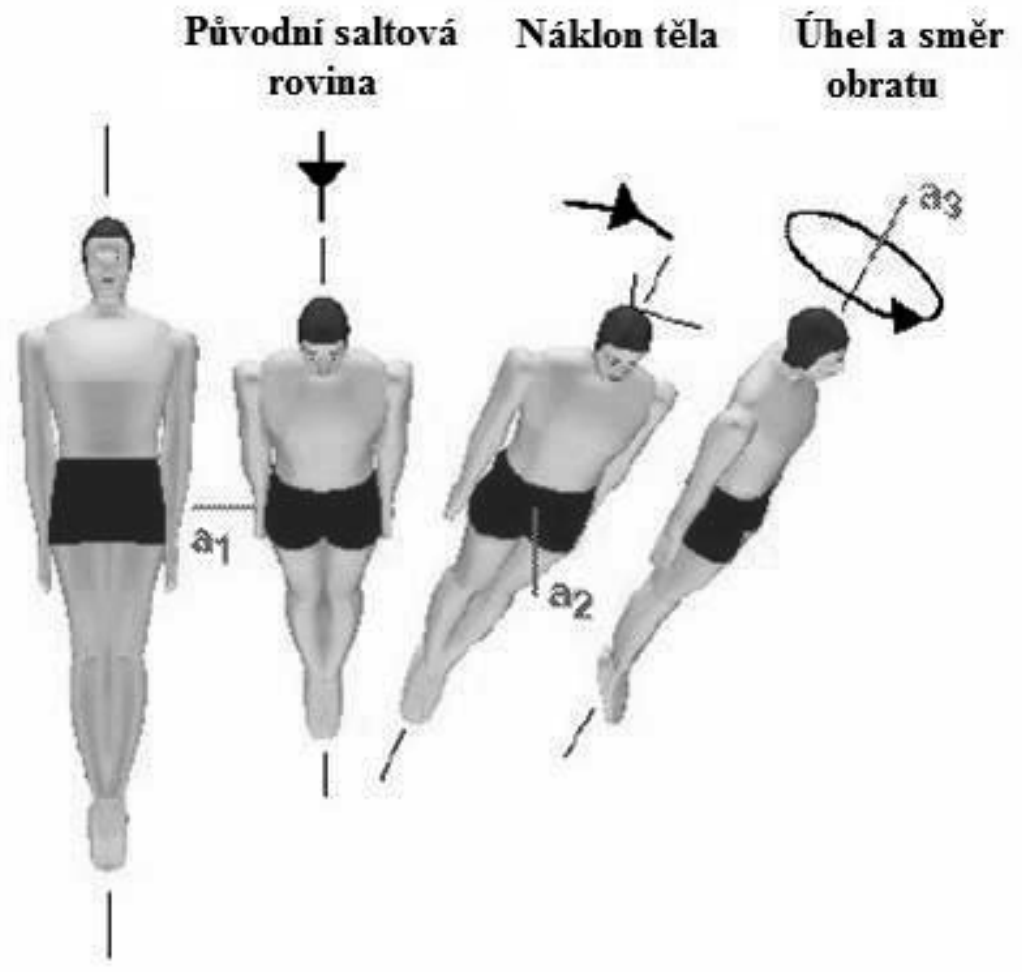

Obrázek 2. Původní saltová rovina, úhel náklonu těla od původní saltové roviny a úhel a směr obratů (použito a upraveno podle Yeadon, 2000)

Druhá část (Yeadon, 1993b) popisuje vztahy mezi pohyby segmentů paží, trupu a dolních končetin během fáze kontaktu a odrazu u saltových prvků s rotací kolem vertikální osy otáčení. Tato technika zisku obratů je označována jako „contact twist“. Při této technice získáváme druhotnou rotaci pomocí momentového působení odrazu. To znamená, že tělo gymnasty je při odrazu natočeno ve směru druhotné rotace a obrat je zahájen již ve chvíli, kdy jsou chodidla nebo dlaně v kontaktu s podložkou (odrazový můstek, přeskokový stůl). Tím vzniká moment síly, který uvede tělo do otáčivého pohybu kolem vertikální osy otáčení. Odrazem a aktivním pohybem segmentu paží získává gymnasta moment hybnosti kolem horizontální osy otáčení, přičemž náklonem těla od původní saltové roviny se část momentu hybnosti přenáší na rotaci okolo vertikální osy. Následnou fixací segmentu paží vůči segmentu tru-

5 V angličtině používaný pojem wobbling somersault. 
pu se část momentu hybnosti přenese na trup, který setrvačně pokračuje v rotačním pohybu (Yeadon, 2000). Tento proces je znám jako přenos momentu hybnosti mezi segmenty (Hay, 1993). Zahájení obratů je posíleno náklonem těla od původní saltové roviny. Čím více je tělo v okamžiku odrazu nakloněno, tím rychleji rotuje kolem vertikální osy otáčení. Tato technika provedení obratů je typická pro převratové skoky s vícenásobnými rotacemi kolem vertikální osy otáčení. Např́ílad při skoku přemet vpřed a salto vpřed toporně s obratem $900^{\circ}$ „Yeo“ někteři gymnasté ve fázi kontaktu s přeskokovým stolem mírně předsouvají jednu ruku, čímž natáčejí tělo do směru druhotné rotace, a přenášejí tak část momentu hybnosti na rotaci okolo vertikální osy otáčení. Nevýhodou techniky obratů vznikajících na opoře jsou možné problémy při doskocích, kdy při nedokončení obratu tělo setrvačně pokračuje v rotaci, čímž se výrazně zvyšuje riziko zranění dolních končetin (Yeadon, 1999).

Ve třetí části (Yeadon, 1993c) se autor zabývá způsoby zahájení rotace kolem vertikální osy otáčení za volného letu (v letové fázi) prostřednictvím pohybů segmentů paží, hrudníku, pánve a dolních končetin. Tato technika obratů je označována jako „aerial twist“a je náročnější na časoprostorové relace pohybu. Autor popisuje dvě techniky vzniku obratů za volného letu. Při prvním způsobu, označovaném jako protirotační technika ${ }^{6}$, je obrat zahájen rotací segmentu s menším momentem setrvačnosti proti segmentu s vyšším momentem setrvačnosti. Např́ílad při saltu vpřed s obratem o $180^{\circ}$ je obrat zahájen rotací segmentu dolních končetin vủči segmentu trupu, který má vzhledem k dolním končetinám vyšší moment setrvačnosti. Stejnou technikou je proveden obrat $\mathrm{u}$ jednoho $\mathrm{z}$ nejsložitějších přeskoků - přemet vpřed a dvojné salto vpřed skrčmo s obratem $180^{\circ}$ „Dragulescu“. Podobný způsob zisku druhotné rotace je označován jako „hula hop“ nebo „kočičí“ technika (Hay, 1993; Yeadon, 1993c, 1999, 2000). Pohybem pánve do strany z prohnutí do vysazení dochází za letu k naklonění těla od původní saltové roviny, a tím i ke vzniku druhotné rotace. Při obratu vlevo je rotace zahájena $\mathrm{z}$ toporné pozice těla flexí $\mathrm{v}$ pravém boku. Kočičí technika $a^{7}$ byla vypozorována u koček, které se za volného letu dokážou torzními pohyby páteře dostat do rotačního pohybu a vždy dopadnout na nohy. Tyto techniky vzniku druhotné rotace jsou náročné a jsou pro ně potřeba dostatečné časově-prostorové parametry pohybu.

Druhá technika vzniku obratu je založena na úklonu těla od původní vertikální saltové roviny prostř̌ednictvím asymetrických pohybů pažî ${ }^{\otimes}$. Např́ílad připažením pravé a vzpažením levé nakloníme tělo doleva od původní saltové roviny a důsledkem náklonu začne tělo gymnasty rotovat kolem vertikální osy otáčení. Carr (2004) uvádí, že naklonění těla o $5^{\circ}$ od původní vertikální saltové roviny je impulsem pro zahájení obratů kolem vertikální osy. Rychlost rotace zvýšíme snížením momentu setrvačnosti. Úhel náklonu těla způsobený v důsledku abdukce paže podle Yeadona (1993c) ukazuje tabulka 1.

Tabulka 1. Úhel náklonu těla způsobený v důsledku abdukce paže (Yeadon, 1993c)

\begin{tabular}{|c|c|}
\hline $\begin{array}{c}\text { Abdukce paže } \\
\left({ }^{\circ}\right)\end{array}$ & Úhel náklonu těla $\left(^{\circ}\right)$ \\
\hline $0^{\circ}$ & $0^{\circ}$ \\
\hline $30^{\circ}$ & $0^{\circ}$ \\
\hline $60^{\circ}$ & $0,5^{\circ}$ \\
\hline $90^{\circ}$ & $1,5^{\circ}$ \\
\hline $120^{\circ}$ & $3,1^{\circ}$ \\
\hline $150^{\circ}$ & $4,9^{\circ}$ \\
\hline $180^{\circ}$ & $6,9^{\circ}$ \\
\hline
\end{tabular}

$6 \mathrm{~V}$ angličtině používaný pojem counter-rotation twist nebo action-reaction twist.

$7 \mathrm{~V}$ angličtině používaný pojem cat technique nebo cat twist. 
Jiným problémem rotací kolem vertikální osy je směr obratů. Jedním z faktorů, od kterého se směr obratů odvijí, je laterální preference každého gymnasty. Gymnasté ve velmi brzkém věku zjištují, zda budou točit obraty doprava nebo doleva, a obvykle udržují tuto preferenci po celou svou kariéru (Arkaev a Suchilin, 2004). Sands (2000) analyzoval 5 odlišných cvičebních tvarů se zaměřením na směr rotace (salto vpřed s obratem, salto vzad s obratem, vertikální skok s obratem, pirueta a rondát). Výsledky studie ukazují, že více než $76 \%$ gymnastek, které dělají rondát na pravou stranu, v ostatních čtyřech cvičebních tvarech točí obraty vlevo. K podobným výsledkům došli Heinen, Vinken a Velentzas (2010), kteří uvádí, že gymnastky, které provádějí vertikální skok s obratem vlevo, obvykle dělají rondát vpravo a následné salto vzad s obratem opět vlevo.

\section{Diskuse}

Klíčovou roli v současném provedení přeskoku hraje rotační pohyb kolem horizontální a vertikální osy otáčení. Počet a také kvalita rotací je určena především množstvím momentu hybnosti, který je gymnasta schopen získat na odraze a následně ho využít v dalších fázích skoku (např. zvyšováním nebo snižování momentu setrvačnosti). Někteří autoři prezentují závěry přemetových skoků různých obtížností: přemet vpřed (Takei, 1989), přemet vpřed a salto vpřed skrčmo (Takei, 1988; Takei a Kim, 1990), přemet vpřed a dvojné salto vpřed skrčmo „Roche“ (Takei, Dunn a Blucker, 2003, 2007). Přemet vpřed je základním převratovým skokem, od jeho úspěšného osvojení se odvíjí nácvik složitějších přeskoků. Jak uvádí Takei (1989), dosahuje moment hybnosti u přemetu vpřed $95 \mathrm{~kg} \cdot \mathrm{m}^{2} \cdot \mathrm{s}^{-1} \pm 17 \mathrm{~kg} \cdot \mathrm{m}^{2} \cdot \mathrm{s}^{-1} \mathrm{v}$ první letové fázi a $45 \mathrm{~kg} \cdot \mathrm{m}^{2} \cdot \mathrm{s}^{-1} \pm 8 \mathrm{~kg} \cdot \mathrm{m}^{2} \cdot \mathrm{s}^{-1}$ ve druhé letové fázi. Takei (1988) zjistil u přemetu vpřed a salta vpřed skrčmo moment hybnosti první a druhé letové fáze $111 \mathrm{~kg} \cdot \mathrm{m}^{2} . \mathrm{s}^{-1}$, resp. $64 \mathrm{~kg} \cdot \mathrm{m}^{2} . \mathrm{s}^{-1}$. Je tedy zřejmé, že s rostoucí složitostí skoku vzrůstá i potřeba vyššího momentu hybnosti. Takei et al. (2003) považují moment hybnosti za klíčový faktor úspěšného provedení přeskoku přemet vpřed a dvojné salto vpřed skrčmo „Roche“. Nicméně nenalezli signifikantní rozdíly mezi skoky s vysokým $(\mathrm{n}=16)$ a nízkým $(\mathrm{n}=16)$ bodovým hodnocením. U skoků s vyšším hodnocením nalezli Takei et al. (2007) vyšší hodnoty momentu setrvačnosti. To bylo způsobeno vyšší vertikální rychlostí při odrazu z nářadí a delší dobou trvání druhé letové fáze. Gymnasté tak měli dostatek času pro dokončení dvojného salta a mohli tak být během druhé letové fáze ve více otevřené poloze skrčmo (více rozbalení).

Rovněž u skoků ze skupiny „Yurchenko“ je moment hybnosti získaný ve fázi odrazu z můstku klíčovým faktorem pro další fáze skoku (Kwon, Fortney a Shin, 1990; Koh, Jennings, Elliott a Lloyd, 2003; Koh a Jennings, 2007). Koh a Jennings (2007) uvádějí, že získáním vysokého momentu hybnosti lze kompenzovat nižší dráhu těžišsě těla, a tím i kratší dobu trvání druhé letové fáze. Vyšší hodnoty momentu hybnosti u skoku „Yurchenko“ dosáhne gymnasta rychlým vzpažením ve fázi odrazu z můstku a dosažením vyšší hodnoty úhlu v ramenním kloubu ve fázi kontaktu s přeskokovým nářadím. Koh et al. (2003) optimalizovali tento úhel pomocí počítačové simulace na hodnotu $169^{\circ}$. Brüggemann (1987) uvádí, že malý úhel v ramenním kloubu při kontaktu s nářadím je hlavní přičinou vysoké ztráty získaného momentu hybnosti a vede k nedokončení rotace během druhé letové fáze. To může být jedním z důvodu, proč nejsou skoky ze skupiny „Yurchenko“ vhodné pro gymnasty, kteří nemají dostatečnou úroveň flexibility v ramenním kloubu. Další studie potvrzují, že ve fázi kontaktu a odrazu z přeskokového nářadí dochází ke ztrátě momentu hybnosti (Takei, 1989; Takei a Kim, 1990). Nicméně gymnasté vyšší výkonnosti dokážou tuto ztrátu minimalizovat, přičemž získají vysokou vertikální rychlost nezbytnou pro dostatečnou výšku těžiště těla během druhé letové fáze (Prassas et al., 2006).

Důležitým problémem je směr druhotné rotace z hlediska laterální preference. Brown, Tolmsa a Kamen (1983) nenalezli signifikantní vztah mezi laterální preferencí ruky, oka a směrem rotace při obratech. Sands (2000) tvrdí, že v procesu motorického učení by měli gymnasté zkoušet obraty na obě strany, a tím zjištovat, na kterou stranu je pro ně točivost přirozenější. Závěry dalších studií poukazují na fakt, že pokud při rondátu pokládá gymnastka na podložku nejprve levou ruku (rondát vpravo), pak směr druhotné rotace v následném saltu bude rovněž doleva (Sands, 2000; Heinen et al., 2010). Je tedy otázkou pro další výzkumy, zda lze rondát považovat za cvičební tvar, podle kterého je možné spolehlivě 
predikovat směr druhotné rotace při provedení salt s obraty, nebo zda je směr obratů subjektivní a individuální záležitostí každého gymnasty a gymnastky.

\section{Závěr}

Analýzy pohybových činností přinesly do tréninkové praxe ve sportovní gymnastice poznatky o základní mechanice provedení salt a obratů. Tyto poznatky poskytují sportovcům a trenérům návod, jak si osvojovat a zlepšovat techniku obratů. Gymnasta může obrat zahájit při odrazu (contact twist) nebo $\mathrm{v}$ letové fázi (aerial twist). Obrat je v obou př́padech zahájen náklonem těla od původní saltové roviny. Náklon těla za letu je proveden prostřednictvím asymetrických pohybů paží nebo boků. Rychlost rotace obratu je závislá na velikosti náklonu těla, které musí být toporné a zpevněné. Rychlým přitažením horních končetin k tělu gymnasta sníží moment setrvačnosti kolem osy otáčení, a zrychlí tím rotaci těla. Obrat za letu je zastaven návratem těla zpět $k$ původní saltové rovině a zvýšením momentu setrvačnosti. Při obratech v letové fázi je gymnasta schopen lépe kontrolovat průběh pohybu, nicméně tato technika je náročnější na časoprostorové parametry pohybu. Nevýhodou obratů zahájených při odrazu je obtížnost zastavení rotace, což zvyšuje riziko zranění při doskocích. Trenéři by proto měli v počátcích procesu motorického učení své svěřence učit techniku vzniku druhotné rotace za volného letu.

Nové přeskokové nářadí umožňuje gymnastům produkovat větší moment hybnosti, a dovoluje tak provádět komplexnější a složitější skoky s vícenásobnými rotacemi kolem horizontální a vertikální osy otáčení. Právě technika provedení odrazu s minimální ztrátou momentu hybnosti je klíčovou fází pro úspěšné provedení druhé letové fáze skoku. Při nácviku je ale nutné dbát na správnou techniku provedení rotačních pohybů, čímž minimalizujeme riziko zranění gymnastů a gymnastek. V tréninkové praxi je nutné si uvědomit, že kvalita provedení salt a obratů musí vždy převyšovat jejich kvantitu. Proto je lepší osvojit si a zvládnout např. salto s půlobratem v technicky dokonalém provedení, než se za každou cenu snažit provést salto s vícenásobnými obraty, a vystavovat se tak riziku zranění.

\section{Literatura}

Arkaev, L., Suchilin, N. (2004). Gymnastics: How to create champions. Maidenhead: Meyer and Meyer Sport.

Brown, J.J., Tolsma, B.B., Kamen, G.G. (1983). Relationships between hand and eye dominance and direction of experienced gymnasts and non-athletes. Perceptual \& Motor Skills, 57, 2, 470.

Brüggemann, G.P. (1987). Biomechanics in gymnastics. In B. Van Gheluwe, J. Atha (Eds.), Current Research in Sport Biomechanics. Medicine and Sport Science. Basel: Karger.

Carr, G. (2004). Sports mechanics for coaches (2nd ed.). Champaign, IL: Human Kinetics.

Čuk, I., \& Karácsony, I. (2004). Vault: Methods, Ideas, Curiosities, History. Ljubljana: ŠTD Sangvinčki.

Čuk, I., \& Ferkolj, M. (2008). Changes in technique of handspring double salto forward

tucked performed on horse and vaulting table. Acta Kinesiologiae Universitatis Tartuensis, 13, 20-30.

Gluck, M. (1982). Mechanics for gymnastics coaching. Springfield: Charles C. Thomas.

Hay, G.J. (1993). The biomechanics of sports technique. Prentice-Hall.

Heinen, T., Vinken, P., Velentzas, K. (2010). Does laterality predict twist direction in gymnastics? Science of Gymnastics Journal, 2,1, 5-14.

Irwin, G., Kerwin, D. (2009). The influence of the vaulting table on the handspring front somersault. Sports Biomechanics, 8, 2, 114-128.

Jandačka, D., Uhlář, R. (2011). Základy biomechaniky sportu a tělesných cvičení. Ostrava: Ostravská univerzita.

Koh, M., Jennings, L., Elliott, B., Lloyd, D. (2003). A prediction of an optimum technique for the women's Yurchenko layout. Journal of Applied Biomechanics, 19, 187-204.

Koh, M., Jennings, L. (2007). Strategies in preflight for an optimal Yurchenko layout vault. Journal of Biomechanics, 40, 6, 1256-1261. 
Krištofič, J. (1996). Fyzikální aspekty sportovní gymnastiky: Kinematická analýza vybraných cvičení ze sportovní gymnastiky. Praha: Karolinum.

Kwon, Y.H., Fortney, V.L., Shin, I.S. (1990). 3-D Analysis of Yurchenko vaults performed by female gymnasts during the 1988 Seoul Olympic games. International Journal of Sport Biomechanics, 6, 157-176. McGinnis, P.M. (2005). Biomechanics of sport and exercise (2nd ed.). Champaign, IL: Human Kinetics. Prassas, S. (1999). Biomechanical research in gymnastics: what is done, what is needed. In XVII International Symposium of Biomechanics in Sports - Acrobatics. Perth: Edith Cowan University.

Prassas, S. (2002). Vaulting mechanics. In XX International Symposium of Biomechanics in Sports. Cáceres: Spain.

Prassas, S., Kwon, Y.H., Sands, W.A. (2006). Biomecanical reasearch in artistic gymnastics: A review. Sports Biomechanics, 5, 2, 261-291.

Rand, T. (2003). New vaulting table. Technique, 23, 1, 9-10.

Sands, W.A. (2000). Twist direction. Technique, 20, 2, 5-7.

Sands, W.A., Caine, D.J., Borms, J. (2003). Scientific aspects of women's gymnastics. S. Karger Publisher.

Sano, S., Ikegami, Y., Nunome, H., Apriantono, T., Sakurai, S. (2007). The continuous measurement of the springboard reaction force in gymnastic vaulting. Journal of Sports Sciences, 25, 4, 381 - 391.

Takei, Y. (1988). Technique used in performing handspring and salto forward tucked in gymnastics vaulting. International Journal of Sport Biomechanics, 4, 260-281.

Takei, Y. (1989). Technique used by elite male gymnasts performing a handspring vault at the 1987 Pan American Games. International Journal of Sport Biomechanics, 5, 1-25.

Takei, Y., Kim, J. (1990). Techniques used in performing the handspring and salto forward tucked vault at the 1988 Olympic Games. International Journal of Applied Biomechanics, 6, 111-138.

Takei, Y., Dunn, H., Blucker, E. (2003). Techniques used in high-scoring and low-scoring 'Roche' vaults performed by elite male gymnasts. Sports Biomechanics, 2, 141-162.

Takei, Y., Dunn, H., Blucker, E. (2007). Somersaulting technique used in high-scoring and low-scoring Roche vaults performed by male olympic gymnasts. Journal of Sports Sciences, 25, 6, 673-685.

Yeadon, M.R. (1993a). The biomechanics of twisting somersaults. Part I: Rigid body motions. Journal of Sports Sciences, 11, 187-198.

Yeadon, M.R. (1993b). The biomechanics of twisting somersaults. Part II: Contact twist. Journal of Sports Sciences, 11, 199-208.

Yeadon, M.R. (1993c). The biomechanics of twisting somersaults. Part III: Aerial twist. Journal of Sports Sciences, 11, 209-218.

Yeadon, M.R. (1993d). The biomechanics of twisting somersaults. Part IV: The biomechanics of twisting somersaults Part IV: Partitioning performances using the tilt angle. Journal of Sports Sciences, 11, 219-225. Yeadon, M.R. (1999). Learning how to twist fast. In XVII International Symposium of Biomechanics in Sports. Perth: Edith Cowan University.

Yeadon, M.R. (2000). The physic of twisting somersaults. Physics World, 13, 9, 33-38.

Yeadon, M.R., Kerwin, D.G. (1999). Contributions of twisting techniques used in backward somersaults with one twist. Journal of Applied Biomechanics, 15, 152-165.

Yeadon, M.R., Atha, J., Hales, F.D. (1990). The simulation of aerial movement - IV: A computer simulation model. Journal of Biomechanics, 23, 85-89. 